Revista Eletrônica de Direito Processual - REDP. Volume 16. Julho a dezembro de 2015

Periódico Semestral da Pós-Graduação Stricto Sensu em Direito Processual da UERJ

Patrono: José Carlos Barbosa Moreira. ISSN 1982-7636. pp. 157-188 http://www.e-publicacoes.uerj.br/index.php/redp/index

\title{
PROCESSO CONSTITUCIONAL: O PROCESSO COMO LOCUS DEVIDO PARA O EXERCÍCIO DA DEMOCRACIA ${ }^{1}$
}

\section{CONSTItUtional PROCESS: THE PROCESS AS A DUE PLACE TO THE EXERCISE OF DEMOCRACY}

\author{
Fernando Laércio Alves da Silva \\ Professor Adjunto I da Universidade Federal de Viçosa/MG. \\ Doutorando em Direito Processual pela PUCMINAS. Mestre em \\ Direito pela UNIFLU. Bolsista CAPES. \\ fernando.laercio@ufv.br
}

RESUMO: Em 1984, José Alfredo de Oliveira Baracho publicou, no Brasil, a obra intitulada Processo Constitucional, por meio da qual pioneiramente apresentou os elementos de conexão entre Constituição e Processo, levando a uma radical mudança na perspectiva pela qual se concebe o Direito Processual e sua importância para a construção do Estado Democrático de Direito. Mais de trinta anos depois, intensas tem sido as pesquisas jurídicas a partir da teoria do processo constitucional não apenas nos tradicionais campos do Direito Processual, como também em ramos do direito público como o direito constitucional, direito administrativo e direito eleitoral. Não obstante isso, ainda se percebe certos equívocos e incompreensões tanto em relação aos elementos estruturais do processo constitucional como em relação a sua importância para o Direito. Diante disso, o presente trabalho tem por objetivo a retomada dos elementos estruturais do processo constitucional de modo a tentar afastar quaisquer equívocos ainda existentes quanto à abrangência e a profundidade dessa importante teoria processual.

PALAVRAS-CHAVE: Processo constitucional; democracia; modelo constitucional de processo; teoria geral do processo.

\footnotetext{
${ }^{1}$ Artigo recebido em 30/09/2015 e aprovado em 27/11/2015.
} 
Revista Eletrônica de Direito Processual - REDP. Volume 16. Julho a dezembro de 2015

Periódico Semestral da Pós-Graduação Stricto Sensu em Direito Processual da UERJ

Patrono: José Carlos Barbosa Moreira. ISSN 1982-7636. pp. 157-188 http://www.e-publicacoes.uerj.br/index.php/redp/index

\begin{abstract}
In 1984, José Alfredo de Oliveira Baracho published in Brazil, the work entitled
Constitutional Process, by which pioneered presented the connecting factors between Constitution and Process, leading to a radical change in perspective from which one sees the Procedural Law and its importance for the construction of a democratic state. More than thirty years later, intense has been the legal research from the theory of the constitutional process not only in traditional fields of Procedural Law, as well as in branches of public law and constitutional law, administrative law and electoral law. Nevertheless, still perceive certain misconceptions and misunderstandings both in relation to the structural elements of the constitutional process as well as its importance to the law. Thus, the present study aims to the resumption of the structural elements of the constitutional process in order to try to remove any remaining misconceptions as to the scope and the depth of this important procedural theory.
\end{abstract}

KEYWORDS: Constitutional procedure; democracy, contradictory; constitucional processo model; general theory of process

SUMÁRIO: 1. Considerações introdutórias. 2. A inafastável relação entre Estado Democrático de Direito e Processo. 3. Processo constitucional: o processo como metodologia de garantias dos direitos fundamentais. 4. Considerações finais. Referências bibliográficas.

\title{
1. Considerações introdutórias
}

Nos últimos vinte e cinco anos, inúmeros estudos têm sido desenvolvidos no Brasil com o objetivo de promover a releitura ou reconstrução dos diversos campos do saber jurídico a partir do arcabouço principiológico constitucional. Este processo de constitucionalização do direito, identificado por Virgílio Afonso da Silva - com amparo na doutrina de Louis Favoreu - como constitucionalização-transformação, se caracteriza pela "mudança do conteúdo dos outros ramos do direito provocada pela constituição"2 como consequência da

\footnotetext{
${ }^{2}$ SILVA, Virgílio Afonso. A Constitucionalização do Direito: Os direitos fundamentais nas relações entre particulares, p. 48.
} 
Revista Eletrônica de Direito Processual - REDP. Volume 16. Julho a dezembro de 2015

Periódico Semestral da Pós-Graduação Stricto Sensu em Direito Processual da UERJ

Patrono: José Carlos Barbosa Moreira. ISSN 1982-7636. pp. 157-188

http://www.e-publicacoes.uerj.br/index.php/redp/index

constitucionalização dos direitos e liberdades, impregnando, em sua essência, todos os campos

do Direito.

A partir desse movimento, torna-se comum falar-se, por exemplo, em direito civil constitucional, direito penal constitucional, direito do trabalho constitucional, direito ambiental constitucional, direito administrativo constitucional, expressões utilizadas prodigamente pelos autores destes tradicionais campos do pensamento jurídico, sempre no intuito de trabalhar seus institutos a partir de uma nova perspectiva, qual seja, a perspectiva dos princípios constitucionais.

Essa nova metodologia de trabalho do (e no) Direito, no Brasil, como já mencionado, é relativamente recente, remontando à década de oitenta do século passado. Isso porque, somente a partir do fim do governo ditatorial e, principalmente, da promulgação da Constituição Federal de 1988, foi que se encontrou campo fértil para seu florescimento 3 .

Tudo isso se deve à opção constitucional realizada em 1988 de se reinstituir ${ }^{4}$ no Brasil a estrutura de um Estado Democrático de Direito, "que se empenha em assegurar aos seus cidadãos o exercício efetivo não somente dos direitos civis e políticos, mas também e sobretudo dos direitos econômicos, sociais e culturais, sem o quais de nada valeria a solene proclamação daqueles direitos" $"$.

É exatamente esse compromisso constitucional de empenhar-se em assegurar aos cidadãos o efetivo exercício de seus direitos no Estado Democrático de Direito que leva à mudança do conteúdo dos diversos campos do Direito. Neste contexto, a relação entre Constituição e Processo, sem demérito à relação estabelecida entre a Constituição e os demais campos jurídicos, se mostra de natureza ímpar.

\footnotetext{
${ }^{3}$ De fato, embora na Europa a constitucionalização dos direitos e das liberdades tenha se desenvolvido de longa data (referências são a Declaração Universal dos Direitos do Homem da ONU, de 1948 e as Constituições da Alemanha, originalmente chamada Lei Fundamental de Bonn e, desde a reunificação alemã, Lei Fundamental da República Federal da Alemanha, de 1949, e da Itália, de 1947), no Brasil, como em quase todos os demais Estados latino-americanos, somente após o encerramento do ciclo dos governos ditatoriais foi possível alcançar tal intento.

${ }^{4}$ André Del Negri questiona se, de fato, é possível falar-se em reinstituição ou retorno da democracia no Brasil, tendo em vista o fato de, em quase duzentos anos de emancipação política em relação a Portugal, nunca se ter conseguido no Brasil implantar e manter a democracia de maneira estável e segura (Controle de Constitucionalidade no Processo Legislativo: teoria da legitimidade democrática, p. 76).

${ }^{5}$ MENDES, Gilmar Ferreira; MÁRTIRES COELHO, Inocêncio; GONET BRANCO, Paulo Gustavo. Curso de Direito Constitucional, p. 149.
} 
Revista Eletrônica de Direito Processual - REDP. Volume 16. Julho a dezembro de 2015

Periódico Semestral da Pós-Graduação Stricto Sensu em Direito Processual da UERJ

Patrono: José Carlos Barbosa Moreira. ISSN 1982-7636. pp. 157-188 http://www.e-publicacoes.uerj.br/index.php/redp/index

Isso porque, no campo processual, a inclusão da expressão constitucional ao final da tradicional denominação do campo jurídico direito processual - direito processual constitucional - adquire conotação mais ampla do que nos demais campos. Falar, portanto, em processo constitucional não implica apenas na releitura dos institutos processuais a partir do arcabouço principiológico constitucional. Mais que isso, determina o repensar do próprio processo - e, consequentemente, do direito processual -, alçado à condição de instrumento de garantias dos cidadãos.

O problema é que, quando se passa ao exame do conteúdo dos textos elaborados pelos diversos autores acerca do papel e da estrutura do processo brasileiro no Estado Democrático de Direito instituído em 1988, percebe-se que muitos ainda não compreenderam a profundidade da questão e continuam a trabalhar o processo - e o direito processual - como um instrumento para a efetivação de valores, a realização da justiça social e, até mesmo, o cumprimento de uma função educativa da sociedade. Tal posicionamento revela uma visão equivocada do Estado brasileiro pós 1988, compreendendo sua modelação não como um Estado Democrático de Direito, mas como um Estado Social ${ }^{6}$.

Diante desse problema, neste breve trabalho, propõe-se a discutir a correta relação que se estabelece entre Constituição e processo no Brasil, tendo em vista o advento da Constituição Federal de 1988 e, a partir de então, demonstrar o que, realmente, se deve compreender por processo constitucional no Estado Democrático de Direito e o contributo que ele tem a oferecer para a conformação do Brasil como um efetivo Estado Democrático de Direito.

O desenvolvimento da empreitada ora proposta tomará por marco teórico o pensamento de José Alfredo de Oliveira Baracho, introdutor da temática no Brasil ${ }^{7}$, e dos pesquisadores que, por ele influenciados, têm aprofundado o estudo do processo constitucional no Brasil, dentre os quais Marcelo Cattoni de Oliveira, Ronaldo Brêtas, André Del Negri e Dierle Nunes.

Para tanto, estruturalmente, o trabalho compõe-se por duas partes. O primeiro deles volta-se à exposição da relação entre Estado Democrático de Direito e Processo, relevante para o correto enquadramento do processo constitucional na contemporaneidade. Já o segundo tem

\footnotetext{
${ }^{6}$ Nesse sentido, podem ser citadas as manifestações de Cândido Rangel Dinamarco (A Instrumentalidade do Processo), Rui Portanova (Princípios do processo civil), Maria Cecília Máximo Teodoro (O Juiz Ativo e os Direitos Trabalhistas) ou de Fernando da Costa Tourinho Filho (Processo Penal).

${ }^{7}$ BARACHO, José Alfredo de Oliveira. Processo Constitucional.
} 
Revista Eletrônica de Direito Processual - REDP. Volume 16. Julho a dezembro de 2015

Periódico Semestral da Pós-Graduação Stricto Sensu em Direito Processual da UERJ

Patrono: José Carlos Barbosa Moreira. ISSN 1982-7636. pp. 157-188 http://www.e-publicacoes.uerj.br/index.php/redp/index

por objeto primeiramente a análise das características do processo constitucional e, em sequência, a apresentação do processo constitucional como instrumento de garantias do cidadão face às funções executiva, legislativa e judicial do Estado brasileiro.

\section{A inafastável relação entre Estado Democrático de Direito e Processo}

2.1. De 1824 a 1988: breve comentário sobre o caminho constitucional brasileiro

Desde a proclamação de sua independência, em 1822, a história do Estado brasileiro sempre foi marcada pela instabilidade e o absoluto desrespeito à legalidade constitucional. Aliás, a postura adotada por D. Pedro I, ao dissolver a primeira Assembleia Constituinte brasileira, em 1823, e outorgar um texto constitucional diverso, em 1824, marcado pela concentração do poder nas mãos do monarca, já indicava, de um lado, a não abertura ao pensamento democrático e, de outro, a incompreensão sobre o efetivo papel da Constituição para um Estado já no Século XIX ${ }^{8}$.

Após sessenta e sete anos da outorga da Constituição de 1824, e poucos meses após o início do segundo ano da proclamação da República, em 24 de fevereiro de 1891, o Congresso Constituinte promulgou a primeira constituição republicana brasileira. A despeito de, em seu preâmbulo, mencionar-se a proposta de organização de um regime democrático, e de ter buscado inspiração nas Constituições norte-americana, suíça e argentina, tacanha era concepção de democracia adotada e limitada era a vinculação do texto com a realidade brasileira. Esses aspectos, aliados aos diversos conflitos de poderes, tanto nas forças armadas como entre os estados da Federação, resultaram na revolução de 1930 e à substituição do texto constitucional de 1891 pelo de $1934^{9}$.

\footnotetext{
${ }^{8}$ Sobre o momento histórico brasileiro ora citado, Luís Roberto Barroso e Ana Paula de Barcellos chegam a dizer que o "desrespeito à legalidade constitucional acompanha a evolução política brasileira como uma maldição, desde que D. Pedro I dissolveu a primeira Assembléia Constituinte" (O começo da história: a nova interpretação constitucional e o papel dos principios no Direito Brasileiro. In: SILVA, Virgílio Afonso (org.) Interpretação Constitucional, p. 272).

${ }^{9}$ SILVA, José Afonso da. Curso de Direito Constitucional Positivo, p. 79-81.
} 
Revista Eletrônica de Direito Processual - REDP. Volume 16. Julho a dezembro de 2015

Periódico Semestral da Pós-Graduação Stricto Sensu em Direito Processual da UERJ

Patrono: José Carlos Barbosa Moreira. ISSN 1982-7636. pp. 157-188 http://www.e-publicacoes.uerj.br/index.php/redp/index

Quatro anos depois da Revolução de 1930, e ainda com Getúlio Vargas na Presidência

da República ${ }^{10}$, em 1934, a Assembleia Nacional Constituinte promulgou a terceira Constituição Brasileira, a segunda desde o rompimento com o regime monárquico e a instituição do republicano. A leitura, ainda que superficial, do texto constitucional de 1934 permite verificar ter sido ele o primeiro no qual, de maneira clara, vinculou-se ao princípio democrático, fazendose constar, em seu art. $2^{\circ}$, que "todos os poderes emanam do povo e em nome dele são exercidos". Não obstante isso, aparentemente, a maldição constitucional brasileira, mencionada por Luís Roberto Barroso e Ana Paula de Barcellos, novamente se manifestou. Isso porque, em 1937, Vargas dissolveu a Câmara e o Senado e outorgou a terceira Constituição Brasileira, a Polaca, com forte inspiração fascista e, portanto, alheia a qualquer inspiração democrática ${ }^{11}$, com base na qual se manteve na Presidência da República até 1945, quando, por Golpe Militar, foi deposto.

Destituído Vargas ${ }^{12}$, em 1946, a Assembleia Nacional Constituinte promulgou a quarta Constituição Federal brasileira, inspirada nos textos constitucionais de 1891 e 1934, novamente orientada pela tentativa de instituir a base democrática no Brasil. Ainda nesse período, a visão brasileira de democracia se mostrava extremamente míope, não se conseguindo acompanhar o avanço verificado na Europa, especialmente na então Alemanha Ocidental (Lei Fundamental de

\footnotetext{
${ }^{10}$ Do ponto de vista técnico-formal, os Manuais de Direito Constitucional que abordam a história constitucional nacional se equivocam ao tratar da Era Vargas. Isso porque, direta ou subliminarmente, transmitem a informação de que Vargas, líder da Revolução de 1930, teria imediatamente assumido a Presidência da República. Desse modo, ao leitor desavisado poderia parecer que ele, Getúlio Vargas, ante o fato de Júlio Prestes não ter assumido a presidência, teria sido o sucessor de Washington Luís no cargo, informação essa absolutamente equivocada. Isso porque, entre 24 de outubro e 03 de novembro de 1930, o Executivo Federal permaneceu sob o comando de uma Junta Provisória, composta por Augusto Tasso Fragoso (General), Isaías de Noronha (Almirante) e João Mena Barreto (General). Somente em 03 de novembro de 1930 a Junta Provisória cedeu a Chefia do Executivo a Getúlio Vargas.

${ }^{11}$ A despeito de, em seu art. $1^{\circ}$ a Constituição de 1937, tal como a de 1934, dispor que o poder emanava do povo, acresceu que tal poder era exercido em nome desse povo "e no interesse do seu bem-estar, da sua honra, da sua independência e da sua prosperidade", assumindo, portanto, forte traço de um Estado Social. Além disso, apesar do art. 187 da Constituição de 1937 determinar a realização de plebiscito para ratificação do texto outorgado e, em seu art. 178 - o mesmo com base no qual se dissolveu Câmara e o Senado - restar determinada a realização de eleições para o Parlamento nacional logo após o supracitado plebiscito, Vargas jamais determinou nem a realização do plebiscito e nem as eleições para o Parlamento nacional. Diante disso, entre 1937 e 1945 - ano de sua deposição - vigorou no Brasil pura e simplesmente o regime ditatorial varguista.

${ }^{12}$ Após a deposição de Vargas, José Linhares, nos termos do art. 79, §1 ${ }^{\circ}$ da Constituição de 1937, por se tratar do Presidente do Supremo Tribunal Federal à época, assumiu interinamente a Presidência da República. Tão-logo assumiu a Presidência da República, José Linhares tomou as medidas necessárias à convocação de eleições diretas tanto para a Presidência da República como para o Parlamento, restando eleito, para o cargo de Presidente da República Eurico Gaspar Dutra (General).
} 
Revista Eletrônica de Direito Processual - REDP. Volume 16. Julho a dezembro de 2015

Periódico Semestral da Pós-Graduação Stricto Sensu em Direito Processual da UERJ

Patrono: José Carlos Barbosa Moreira. ISSN 1982-7636. pp. 157-188

http://www.e-publicacoes.uerj.br/index.php/redp/index

Bonn, de 1949) ou na Itália (Constituição Italiana de 1947), onde o pós-Segunda Guerra foi marcado pela preocupação com a concretização dos direitos fundamentais, o que, por óbvio, não prescindia da conformação estatal sob os efetivos moldes de Estado Democrático de Direito ${ }^{13}$.

O projeto de redemocratização instituído em 1946 ruiu com o Golpe Militar de 1964. Instalado o Governo Militar, em 1967, o Congresso Nacional promulgou uma nova Constituição Federal, cujo projeto, fortemente influenciado pela Polaca de Vargas, fora apresentado ao Congresso pelo Executivo ao final do ano anterior. Mais autoritária entre todas as Constituições Brasileiras até então vigentes, a Constituição de 1967 restou ainda mais autoritária após a Emenda Constitucional $\mathrm{n}^{\mathrm{o}}$ 01, de 1969, que, apesar de ter sido chamada de emenda constitucional, em verdade, alterou o texto de 1967 em sua quase plenitude, sendo, técnica e teoricamente um novo texto constitucional ${ }^{14}$.

Mais de vinte anos depois, somente em 1988, a nova - e atualmente em vigor Constituição Federal foi promulgada, consistindo, para Luís Roberto Barroso, no "símbolo maior de uma história de sucesso: a transição de um Estado autoritário, intolerante e, muitas vezes, violento para um Estado democrático de direito"15. Mais do que apenas um símbolo, de todos os textos constitucionais vigentes do Brasil desde o de 1824, a Constituição Federal de 1988 foi a primeira a, mais do que reconhecer que o poder emana do povo, instituir o Estado Democrático de Direito efetivamente como seu princípio fundamental (o que se verifica já no caput de seu art. $1^{\circ}$ ) e, portanto, condutor de toda a atividade estatal, estabelecendo criteriosamente os instrumentos para sua concretização.

\footnotetext{
${ }^{13}$ Sobre a preocupação com a proteção dos direitos fundamentais como resposta às atrocidades cometidas na Segunda Guerra, Ronaldo Brêtas ensina que elas motivaram “(...) a preocupação de se incluir um catálogo de proteção dos direitos humanos nos textos dos tratados internacionais e das Constituições surgidos após aquele sombrio período histórico, que não pode jamais ser esquecido, sob pena de fatídica repetição" e que "(...) o reconhecimento expresso dos direitos fundamentais nos textos constitucionais e ordenamentos jurídicos infraconstitucionais contemporâneos permitiu a criação de um bloco compacto de salvaguarda das pessoas e de suas liberdades contra quaisquer atos de abuso do poder ou de arbítrio provenientes do Estado, incompatíveis com o princípio maior da vinculação de qualquer ato estatal ao Estado Democrático de Direito (...)" (BRÊTAS, Ronaldo de Carvalho Dias. Processo Constitucional e Estado Democrático de Direito, p. 69-70).

${ }^{14}$ José Afonso da. Curso de Direito Constitucional Positivo, p. 86-87.

${ }^{15}$ BARROSO, Luís Roberto. O Constitucionalismo Democrático no Brasil: Crônica de um sucesso imprevisto. In: GUERRA, Roberta Freitas; SILVA, Fernando Laércio Alves da; DEL NERO, Patrícia Aurélia (org.). Neoconstitucionalismo em perspectiva, p. 28.
} 
Revista Eletrônica de Direito Processual - REDP. Volume 16. Julho a dezembro de 2015

Periódico Semestral da Pós-Graduação Stricto Sensu em Direito Processual da UERJ

Patrono: José Carlos Barbosa Moreira. ISSN 1982-7636. pp. 157-188 http://www.e-publicacoes.uerj.br/index.php/redp/index

Por esse breve e, obviamente, limitado escorço histórico das Constituições percebe-se facilmente a instabilidade constitucional brasileira ao longo de sua história quase bicentenária, como causadora do atraso em sua conformação formal como Estado Democrático de Direito.

\subsection{Estado Democrático de Direito: um princípio a ser esclarecido}

Antes de se adentrar na análise proposta pelo presente tópico, necessário se faz observar que o Estado Democrático de Direito deve ser analisado a partir de sua real natureza, a dizer, um "princípio jurídico constitucionalmente positivado"16, para fazer uso da expressão de Ronaldo Brêtas Negri, e um "marco teórico jurídico-constitucional-democrático adotado no Brasil pela vigente Constituição"17, segundo leciona André Del Negri. Não se trabalhará, portanto, o Estado Democrático de Direito como um paradigma, expressão que, embora empregada rotineiramente no Direito, geralmente tem sido utilizada a partir de uma perspectiva kuhniana ${ }^{18}$, como simples modelo ou padrão de uma espécie de Estado ${ }^{19}$.

Feita essa observação, passa-se ao esclarecimento do conteúdo do princípio do Estado Democrático de Direito e, consequentemente, da importância de sua expressa inserção já no art. $1^{\circ}$ da Constituição Federal de 1988. Tal esclarecimento se mostra necessário tendo em vista a estruturação do texto constitucional brasileiro de 1988 que consagrou, além dos direitos fundamentais clássicos, de cunho meramente protetivo ou liberal, também os direitos fundamentais de caráter social ${ }^{20}$.

\footnotetext{
${ }^{16}$ Processo Constitucional e Estado Democrático de Direito, p. 57.

${ }^{17}$ Controle de Constitucionalidade no Processo Legislativo: teoria da legitimidade democrática, p. 26.

${ }^{18} \mathrm{O}$ significado de paradigma na perspectiva de Thomas Kuhn é profundamente trabalhado por Menelick de Carvalho Netto [A Hermenêutica Constitucional sob o paradigma do Estado Democrático de Direito. In: CATTONI DE OLIVEIRA, Marcelo Andrade (coord.). Jurisdição e Hermenêutica Constitucional no Estado Democrático de Direito, p. 29], por Marcelo Andrade Cattoni de Oliveira (Direito Constitucional, p. 52) e por Vinícius Lott Thibau (Presunção e Prova no Direito Processual Democrático, p. 06).

${ }^{19}$ Ainda que a expressão paradigma venha a aparecer no corpo do presente trabalho - o que, de plano se esclarece, ocorrerá apenas se utilizada por algum autor acaso citado - deverá ser compreendida pelo leitor não na perspectiva kuhniana, mas sim com o significado de sistema jurídico-normativo consistente, aderindo-se, portanto, ao ensinamento de Ronaldo Brêtas.

${ }^{20}$ SILVA, Virgílio Afonso. A Constitucionalização do Direito: Os direitos fundamentais nas relações entre particulares, p. 23.
} 
Revista Eletrônica de Direito Processual - REDP. Volume 16. Julho a dezembro de 2015

Periódico Semestral da Pós-Graduação Stricto Sensu em Direito Processual da UERJ

Patrono: José Carlos Barbosa Moreira. ISSN 1982-7636. pp. 157-188 http://www.e-publicacoes.uerj.br/index.php/redp/index

De fato, diante dessa situação, diversos autores confundem-se ao aproximar o princípio do Estado Democrático de Direito, no Brasil, a uma concepção de Estado Social, bem nos moldes de um welfare state, a exemplo de Cândido Rangel Dinamarco ${ }^{21}$ e Paulo Bonavides ${ }^{22}$.

Com o devido respeito, a compreensão dos citados autores é, em sua essência, equivocada, não podendo se conceber a confusão entre Estado Social e Estado Democrático de Direito ou mesmo tratá-lo como apenas uma evolução daquele.

Em verdade, o Estado Democrático de Direito consiste em uma terceira via à original dicotomia Estado Liberal versus Estado Social, ante a insuficiência destes em alcançar solução efetiva aos problemas das sociedades contemporâneas ${ }^{23}$. Em síntese, o Estado Liberal fora concebido como forma de superação do absolutismo europeu ao longo dos Séculos XVII e XVIII e de se garantir proteção às iniciativas individuais. Não apresentando, entretanto, respostas - mas, ao invés disso causando o aumento - aos problemas sociais decorrentes do crescimento do capitalismo, construiu-se a principiologia do Estado Social, que, igualmente, não se mostrou eficiente no enfrentamento dos problemas sociais e jurídicos existentes. Essa ineficácia na dicotomia Estado Liberal e Estado Social resultou na construção do Estado Democrático de Direito, que não é - isso deve ficar claro - o meio termo, mas uma terceira via entre as construções anteriores ${ }^{24}$. Nas palavras de André Cordeiro Leal, é “nesse ambiente que o Estado Democrático de Direito se apresenta como novo paradigma que, por via do aproveitamento das contribuições dos anteriores, propõe uma perspectiva diferenciada da leitura do Direito, da Constituição e do Estado"25.

\footnotetext{
${ }^{21}$ A instrumentalidade do processo, p. 34.

${ }^{22}$ Bonavides assume ostensivamente tal opinião quando sustenta que: "A Constituição de 1988 é basicamente em muitas de suas dimensões essenciais uma Constituição do Estado social. Portanto, os problemas constitucionais referentes a relações de poderes e exercício de direitos subjetivos têm que ser examinados e resolvidos à luz dos conceitos derivados daquela modalidade de ordenamento" (Curso de Direito Constitucional, p. 371).

${ }^{23}$ THIBAU, Vinicius Lott. O Direito à prova no paradigma jurídico-constitucional do Estado Democrático de Direito - considerações sobre a procedimentalidade brasileira. In: TAVARES, Fernando Horta (coord.) Constituição e Processo: Princípios Constitucionais do Processo, p. 307.

${ }^{24}$ Nesse sentido, Lênio Luiz Streck diz que: "O Estado Democrático de Direito representa um plus normativoqualitativo m relação ao Estado Liberal e até mesmo ao Estado Social. A Constituição do Brasil, como as de Portugal, Espanha e Alemanha, por exemplo, e que pese o seu caráter aberto, é uma Constituição voltada para a transformação das estruturas econômicas e sociais. Além da carga elevada de direitos fundamentais e princípios consagradores das promessas da modernidade e do caráter compromissário do texto da Constituição brasileira, este 'traz em seu bojo' os mecanismos para a implantação das políticas do Welfare State" (Jurisdição Constitucional e Decisão Jurídica, p. 42).

${ }^{25}$ O contraditório e a fundamentação das decisões do direito processual democrático, p. 28.
} 
Revista Eletrônica de Direito Processual - REDP. Volume 16. Julho a dezembro de 2015

Periódico Semestral da Pós-Graduação Stricto Sensu em Direito Processual da UERJ

Patrono: José Carlos Barbosa Moreira. ISSN 1982-7636. pp. 157-188 http://www.e-publicacoes.uerj.br/index.php/redp/index

Tendo em vista tanto a delimitação temática como a restrição de páginas, não se ocupará o presente trabalho do estudo distintivo entre o Estado Liberal e o Estado Social, prosseguindo na análise da temática colacionada no título do subitem.

Dessa feita, a correta compreensão do Estado Democrático de Direito somente é alcançada pela análise dos dois princípios que, conjugados, compõem sua nomenclatura: o princípio do Estado de Direito e o princípio do Estado Democrático.

Buscando as origens do Estado de Direito, Ronaldo Brêtas apresenta o seu surgimento como uma oposição ao Estado Iluminista ou Estado-providência, caracterizado pela centralização do poder nas mãos do monarca, que exercia, também, a autoridade religiosa, desvinculado de qualquer concepção moderna de constitucionalismo e cuja missão era a promoção do bem estar dos súditos. Nessa tarefa de oposição e superação do Estado iluminista, o princípio do Estado restou configurado pelas seguintes premissas: império da lei, separação das funções estatais, limitação da atividade administrativa pública pela legalidade e garantia formal e concreta dos direitos e liberdades individuais ${ }^{26}$.

No mesmo sentido, José Cirilo de Vargas disserta que "em oposição aos governos arbitrários, promove-se a passagem do Estado absoluto (onde a vontade do Príncipe tinha força de lei) para o Estado de Direito, em que o comando pertence à vontade impessoal das regras jurídicas". E prossegue o autor para dizer que o regramento jurídico (a Lei) em questão é "produto quase sempre da razão, e que exprime, sempre, a vontade geral" 27.

Diverso, portanto, do que se verificava no Estado absolutista, onde a atuação do Estado traduzia a vontade do monarca (soberano), invencível por qualquer obstáculo, no Estado de Direito, não apenas os indivíduos, mas o próprio Estado tem sua atuação limitada pela lei instituída no interesse e para a proteção dos cidadãos. Nesse sentido, novamente se mostra importante recorrer aos ensinamentos de Ronaldo Brêtas, agora em relação à percepção kelseniana do Estado de Direito:

admitiu Kelsen ser o Estado de Direito uma ordem jurídica relativamente centralizada, dentro da qual a jurisdição e a administração estivessem vinculadas às leis, normas gerais estabelecidas por um parlamento eleito pelo povo, os membros

\footnotetext{
${ }^{26}$ Processo Constitucional e Estado Democrático de Direito, p. 49-51.

${ }^{27}$ Processo Penal e Direitos Fundamentais, p. 42.
} 
Revista Eletrônica de Direito Processual - REDP. Volume 16. Julho a dezembro de 2015

Periódico Semestral da Pós-Graduação Stricto Sensu em Direito Processual da UERJ

Patrono: José Carlos Barbosa Moreira. ISSN 1982-7636. pp. 157-188 http://www.e-publicacoes.uerj.br/index.php/redp/index

do governo fossem responsabilizados pelos seus atos, os tribunais gozassem de independência e certas liberdades fundamentais despontassem garantidas aos cidadãos. $^{28}$

Esse Estado vinculado às leis encontra na Constituição sua viga de sustentação. Por meio dela, "compreendida como organização e limitação do poder político, se juridifica o Estado que, legitimado pelo Direito e pelo regime representativo, passa a ser concebido como Estado de Direito, como Estado Constitucional"29.

Desde o rompimento com o absolutismo, como bem ensina André Luís Del Negri, todo Estado, liberal ou mesmo social, tendo por sua base de sustentação na Constituição, será sempre um Estado de Direito ${ }^{30}$. Daí, inclusive, mesmo nos períodos de governos de exceção brasileiros, a preocupação com a institucionalização do regime por meio de textos constitucionais, ainda que outorgados pelo ditador.

Percebe-se, diante disso, que os Estados contemporâneos somente encontram a legitimação de suas atividades se, ao princípio do Estado de Direito, resta aglutinado o princípio democrático.

Não basta, entretanto, restar expresso no texto constitucional - como, de fato, desde a Constituição de 1934 sempre se fez nas no Brasil - que o poder emana do povo e em seu nome é exercido. Essa técnica de redação normativa, inclusive, embora esteja enraizada na legística constitucional brasileira, se mostra insuficiente para qualquer tentativa de definição do princípio democrático.

Isso porque, o verbo emanar, em sua essência, significa provir, proceder, originar-se. Ora, dizer, então, que o poder emana do povo, em uma leitura rasa e simplista, pode transmitir tão-somente a impressão de que o poder político no Estado Democrático procederia do povo, mas seria exercido apenas por seus delegatários, a partir do que a atuação política do povo se limitaria ao processo de escolha desses delegatários. ${ }^{31}$ Em síntese, uma visão míope do conceito de democracia, que a restringe à democracia representativa.

\footnotetext{
${ }^{28}$ Processo Constitucional e Estado Democrático de Direito, p. 52.

${ }^{29}$ CATTONI DE OLIVEIRA, Marcelo Andrade. Direito Constitucional, p. 56.

${ }^{30}$ Controle de Constitucionalidade no Processo Legislativo: teoria da legitimidade democrática, p. 39.

${ }^{31}$ Em semelhante sentido, André Del Negri observa que: "Há quem sustente que 'democracia' é o governo do povo, pelo povo e para o povo'. É uma retórica que nem chega perto da tensão que esta palavra carrega" (Controle de Constitucionalidade no Processo Legislativo: Teoria da legitimidade democrática, p. 76).
} 
Revista Eletrônica de Direito Processual - REDP. Volume 16. Julho a dezembro de 2015

Periódico Semestral da Pós-Graduação Stricto Sensu em Direito Processual da UERJ

Patrono: José Carlos Barbosa Moreira. ISSN 1982-7636. pp. 157-188 http://www.e-publicacoes.uerj.br/index.php/redp/index

Essa não é - e nem pode ser -, na contemporaneidade, a correta acepção do princípio democrático. Longe disso, deve ele ser compreendido "como institucionalização de processos estruturados por normas que garantam a possibilidade de participação discursiva dos cidadãos no processo de tomada de decisões" ${ }^{32}$. Isso porque, na atual quadra histórica, os conceitos de democracia e cidadania "só se concretizam no momento em que o indivíduo efetivamente se percebe integrante do todo, participando ativamente nos mecanismos de ação política"33 34 .

Materializa-se, portanto, o princípio do Estado Democrático tanto pela garantia ao povo de eleger seus governantes - que devem exercer seus mandatos em nome e no interesse daquele - como pela instituição dos mecanismos de participação direta de todos os potenciais atingidos pelos atos estatais na formação desses atos. Ou seja, o princípio do Estado Democrático, portanto, não alcança apenas a participação na atividade de criação da norma, mas sim toda e qualquer atividade estatal que venha a impactar na vida do indivíduo. Nesse sentido, o povo (cidadãos) legitimado a nomear seus representantes nas Casas Legislativas e na Chefia do Executivo também exerce a democracia por meio da fiscalização das atividades desses órgãos - também pela participação direta, quando for o caso - na formação do ato decisório. Da mesma forma, o povo (aqui considerados os potenciais atingidos concretamente pelo ato decisório) está legitimado, também pelo princípio do Estado Democrático, a participar da construção da decisão a ser proferida pelo Judiciário.

E, diga-se de passagem, essas não são formas alternativas, mas sim complementares e igualmente exigíveis de concretização do princípio do Estado Democrático.

${ }^{32}$ CATtOni DE OliveirA, Marcelo Andrade. Direito Processual Constitucional, p. 171.

${ }^{33}$ SILVA, Fernando Laércio Alves da. Cidadania Participativa: O Caso do Orçamento Municipal de Ipatinga-MG. Interesse Público. n. 33. p. 313.

${ }^{34}$ No mesmo sentido, Habermas sustenta que: "Uma ordem jurídica é legítima na medida em que assegura a autonomia privada e a autonomia cidadã de seus membros, pois ambas são co-originárias; ao mesmo tempo, porém, ela deve sua legitimidade a formas de comunicação nas quais essa autonomia pode manifestar-se e comprovar-se" (Direito e Democracia: entre faticidade e validade, v. II, p. 147). E Gisele Cittadino esclarece: "Com a sua teoria discursiva do direito, Habermas busca revelar que, diferentemente das leis morais - que por si só preenchem a condição de assegurar o livre-arbítrio de cada um com a liberdade de todos -, o direito positivo e o seu potencial coercitivo precisam obter legitimidade através de um procedimento legislativo democrático. Com efeito, como a positividade do direito não pode significar uma espécie de faticidade arbitrária, apenas os procedimentos democráticos de elaboração legislativa são capazes de justificar a idéia de que as normas que integram o direito positivo são passíveis de uma aceitação racional" (Pluralismo, Direito e Justiça Distributiva: Elementos da Filosofia Constitucional Contemporânea, p. 172). 
Revista Eletrônica de Direito Processual - REDP. Volume 16. Julho a dezembro de 2015

Periódico Semestral da Pós-Graduação Stricto Sensu em Direito Processual da UERJ

Patrono: José Carlos Barbosa Moreira. ISSN 1982-7636. pp. 157-188 http://www.e-publicacoes.uerj.br/index.php/redp/index

Dessa feita, como já dito páginas acima, o princípio do Estado Democrático de Direito se compõe pela conjugação dos princípios do Estado de Direito e do Estado Democrático, conjugação essa a ser compreendida não como uma simples justaposição, mas uma efetiva aglutinação dos princípios.

2.3 O processo como locus devido para o exercício da democracia

A partir do momento em que o Estado se baliza, constitucionalmente, pelo princípio do Estado Democrático de Direito, o ponto nevrálgico passa a ser a preocupação com a participação, no discurso, de todos os envolvidos na decisão final a ser tomada (trate-se da edição de uma norma legal, uma decisão judicial ou mesmo um ato administrativo), de modo a alcançar-se uma decisão legítima ${ }^{35}$.

Diante dessa exigência - que compõe a essência do próprio Estado Democrático de Direito - necessária se faz a estruturação do instrumento por meio do qual o povo ${ }^{36}$ possa tomar parte na formação do ato estatal. Inexistindo esse instrumento ou espaço apropriado, o princípio democrático, concretamente, não passaria de um tigre de papel ${ }^{37}$.

Esse espaço apropriado é o processo, única instituição que "reúne garantias dialógicas de liberdade e igualdade do homem ante o Estado na criação e reconstrução permanente das instituições jurídicas" ${ }^{\prime 38}$.

Para que o processo se transforme efetivamente em um "instituto fomentador do jogo democrático", servindo de "baliza e garantia na tomada dos provimentos jurisdicionais, legislativos e administrativos" ${ }^{39}$, não pode mais ser concebido apenas como uma relação jurídica

\footnotetext{
${ }^{35}$ DEL NEGRI, André Luis. Processo Constitucional e Decisão Interna Corporis, p. 65.

${ }^{36}$ Acompanhando o pensamento de Ronaldo Brêtas, povo deve ser compreendido como "a comunidade política do Estado, composta de pessoas livres, dotadas de direitos subjetivos umas em face de outras e perante o próprio Estado, fazendo parte do povo tanto os governados como os governantes" (Processo Constitucional e Estado Democrático de Direito, p. 59).

${ }^{37}$ Nesse sentido, Marcelo Cunha de Araújo sustenta que o “espaço de comunicação entre os 'novos' agentes políticos (cidadãos, e não apenas o discurso das cúpulas interpretativas) deve ser visto como um direito-garantia fundamental para a própria efetividade da democracia. Assim, este 'novo espaço' deve ser garantido pelo Estado a todo cidadão e deve conter características mínimas que permitam a participação do membro da democracia (de modo que reflita sua posição de integrante da comunidade democrática)" (O Novo Processo Constitucional, p. 90).

${ }^{38}$ LEAL, Rosemiro Pereira. Teoria Geral do Processo: primeiros estudos, p. 31.

${ }^{39}$ NUNES, Dierle José Coelho. Processo Jurisdicional Democrático, p. 40.
} 
Revista Eletrônica de Direito Processual - REDP. Volume 16. Julho a dezembro de 2015

Periódico Semestral da Pós-Graduação Stricto Sensu em Direito Processual da UERJ

Patrono: José Carlos Barbosa Moreira. ISSN 1982-7636. pp. 157-188 http://www.e-publicacoes.uerj.br/index.php/redp/index

estabelecida entre o Estado-juiz e as partes ou, menos ainda, como um instrumento a serviço do Estado (Jurisdição) para o atendimento de escopos metajurídicos e a pacificação social, compreensões equivocadas e limitadoras das verdadeiras natureza e característica do processo ${ }^{40}$.

Isso porque, em primeiro plano, admitindo-se o processo como relação jurídica, um dos sujeitos processuais (o autor) inevitavelmente seria titular de direitos sobre o outro, restando, portanto, em condição de superioridade sobre ele. E, nas palavras de Aroldo Plínio Gonçalves, "no processo, não poderia haver tal vínculo entre as partes, porque nenhuma delas pode, juridicamente, impor à outra a prática de qualquer ato processual”41. Em segundo lugar porque a teoria do processo ignora por completo a "tendência de constitucionalização do processo, a partir do momento histórico em que o moderno Estado Democrático de Direito estabeleceu expressamente, no texto da sua Constituição, múltiplas garantias de caráter processual, dentre elas, o contraditório (...)"42. E, em terceiro plano - e aqui a crítica volta-se especificamente ao instrumentalismo -, porque tal linha de pensamento, ao adotar por marco teórico o Estado Social, resta absolutamente incompatível com o princípio do Estado Democrático de Direito.

A correta concepção do processo começa a ser construída a partir dos estudos de Elio Fazzalari, que o compreende como uma espécie do gênero procedimento, ao qual é agregado o contraditório, exercido em simétrica paridade entre as partes ${ }^{43}$. Não se limita a concepção de processo, contudo, ao pensamento de Fazzalari4 ${ }^{44}$, já que este concebeu o contraditório apenas como uma qualidade para sua especificação em relação ao gênero procedimento, sem qualquer preocupação com uma análise constitucional do processo, limitando-se ao campo da técnica ${ }^{45}$.

A construção, portanto, somente se finaliza quando passa a ser reconhecido o processo como uma instituição de base constitucional. Nas palavras de José Alfredo de Oliveira Baracho,

\footnotetext{
${ }^{40}$ A concepção do processo como uma relação jurídica foi desenvolvida por Oskar Von Bülow na obra La Teoria de las Excepciones Procesales y los Presupuestos Procesales, enquanto a percepção instrumentalista do mesmo foi desenvolvida pela chamada Escola Paulista de Processo, tendo por obra de referência A Instrumentalidade do Processo, de Cândido Rangel Dinamarco.

${ }^{41}$ Técnica processual e teoria do processo, p. 98.

${ }^{42}$ BRÊTAS, Ronaldo de Carvalho Dias. Processo Constitucional e Estado Democrático de Direito, p. 89.

${ }^{43}$ Nesse sentido, Ulisses Moura Dalle (Legalidade e arbitrio no processo jurisdicional democrático. Revista Eletrônica de Direito Processual. v. XIII, p. 842) e Marcelo Cattoni de Oliveira (O processo constitucional como instrumento da jurisdição. Revista Eletrônica de Direito Processual. v. XIII, p. constitucional. Revista da Faculdade Mineira de Direito, v. 3, n. 5 e 6, p. 165).

${ }^{44}$ FAZZALARI, Elio. Instituições de Direito Processual, p. 125.

${ }^{45}$ Nesse sentido, Rosemiro Pereira. (Teoria Geral do Processo: primeiros estudos, p. 87) e Dierle José Coelho Nunes (Processo Jurisdicional Democrático, p. 207).
} 
Revista Eletrônica de Direito Processual - REDP. Volume 16. Julho a dezembro de 2015

Periódico Semestral da Pós-Graduação Stricto Sensu em Direito Processual da UERJ

Patrono: José Carlos Barbosa Moreira. ISSN 1982-7636. pp. 157-188 http://www.e-publicacoes.uerj.br/index.php/redp/index

a "Constituição pressupõe a existência do processo como garantia da pessoa humana", passando a reconhecer "a necessidade de proclamação programática do princípio do direito processual necessário, no conjunto dos direitos da pessoa humana e garantias respectivas" 46 .

A partir dessa visão, introduzida no Brasil e sistematizada por José Alfredo de Oliveira Baracho $^{47}$, o contraditório é elevado à condição de garantia constitucional, convertendo o processo em uma "metodologia de garantia dos direitos fundamentais" ${ }^{4}$, o locus devido à participação dos legitimados na formação da decisão estatal. Esse locus - processo como metodologia de garantia dos direitos fundamentais -, nas palavras de André Del Negri, "se desenvolve num espaço discursivo de simétrica paridade entre as Partes, de modo que esses sujeitos processuais possam desenvolver seus discursos críticos (isocrítica) e assumir a posição de co-autores interpretativos e fiscalizadores das leis (jurisdição)"49.

\section{Processo constitucional: o processo como metodologia de garantias dos direitos fundamentais}

3.1. Direito Constitucional Processual e Direito Processual Constitucional: uma dicotomia relevante?

José Alfredo de Oliveira Baracho, já no ano de 1984, ou seja, antes mesmo do início dos trabalhos da Assembleia Nacional Constituinte que deu origem à Constituição Federal de 1988, desenvolvia, no Brasil, intensa pesquisa sobre a relação entre Constituição e Processo, sendo um dos responsáveis pela sistematização do processo como metodologia de garantia dos direitos fundamentais, estruturado, portanto, à luz da perspectiva constitucional.

Em verdade, a preocupação com a instituição de mecanismos para o controle da conformidade da norma ordinária com o texto constitucional remonta a Kelsen e à Constituição da Áustria de $1920^{50}$, nos quais se verifica a presença dos primeiros temas do processo

\footnotetext{
${ }^{46}$ Processo Constitucional. Revista Forense. v. 337, p. 106.

${ }^{47}$ BRÊTAS, Ronaldo de Carvalho Dias. Processo Constitucional e Estado Democrático de Direito, p. 93.

48 BARACHO, José Alfredo de Oliveira. Teoria Geral do Processo Constitucional. Revista da Faculdade Mineira de Direito, n. 3 e 4, p. 120.

${ }^{49}$ DEL NEGRI, André Luis. Teoria da Constituição e do Direito Constitucional, p. 346.

${ }^{50}$ BARACHO, José Alfredo de Oliveira. Processo Constitucional. Revista Forense, v. 337, p. 108.
} 
Revista Eletrônica de Direito Processual - REDP. Volume 16. Julho a dezembro de 2015

Periódico Semestral da Pós-Graduação Stricto Sensu em Direito Processual da UERJ

Patrono: José Carlos Barbosa Moreira. ISSN 1982-7636. pp. 157-188 http://www.e-publicacoes.uerj.br/index.php/redp/index

constitucional, a dizer, a jurisdição constitucional (estruturação de um órgão na estrutura do Judiciário especialmente competente para a análise da constitucionalidade das normas legais), o objeto do controle judiciário de constitucionalidade, os critérios para a realização do controle de constitucionalidade, o procedimento para realização desse controle e, por óbvio, o resultado do controle de constitucionalidade. Note-se que, originalmente, o conteúdo do processo constitucional se centrava no exercício da jurisdição constitucional. Somente com o avançar do Século XX e o aprofundamento da teorização em torno dos direitos humanos foi que o processo constitucional teve seu conteúdo ampliado, passando a encampar, também, como constitucionais, os princípios do processo.

Em razão disso, inicialmente se consideravam duas temáticas distintas, de um lado, a constitucionalização dos princípios processuais, sob a denominação de Direito Constitucional Processual, e, de outro, o conjunto normativo constitucional destinado a estruturar o exercício da jurisdição constitucional. Sintetizando a distinção, Marcelo Cattoni de Oliveira menciona que:

O Direito Constitucional Processual seria formado a partir dos princípios basilares do 'devido processo' e do 'acesso à justiça', e se desenvolveria através dos princípios constitucionais referentes às partes, ao juiz, ao Ministério Público, enfim, os princípios do contraditório, da ampla defesa, da proibição das provas ilícitas, da publicidade, da fundamentação das decisões, do duplo grau, da efetividade, do juiz natural, etc.

Já o Direito Processual Constitucional seria formado a partir de normas processuais de organização da Justiça Constitucional e de instrumentos processuais previstos nas Constituições, afetos à 'Garantia da Constituição' e à 'Garantia dos direitos fundamentais', controle de constitucionalidade, solução de conflitos entre os órgãos de cúpula do Estado, resolução de conflitos federativos e regionais, julgamento de agentes políticos, recurso constitucional, Habeas Corpus, Amparo, Mandado de Segurança, Habeas Data, etc. ${ }^{51}$

\footnotetext{
${ }^{51}$ Direito Processual Constitucional, p. 211.
} 
Revista Eletrônica de Direito Processual - REDP. Volume 16. Julho a dezembro de 2015

Periódico Semestral da Pós-Graduação Stricto Sensu em Direito Processual da UERJ

Patrono: José Carlos Barbosa Moreira. ISSN 1982-7636. pp. 157-188 http://www.e-publicacoes.uerj.br/index.php/redp/index

Em outros termos, o Direito Constitucional Processual teria por objeto a estruturação dos processos destinados à formação de atos decisórios estatais em conformidade com as garantias processuais previstas constitucionalmente, ou seja, uma base garantística de observância obrigatória em todo e qualquer processo concreto. Por sua vez, o Direito Processual Constitucional teria por objeto a estruturação da Jurisdição Constitucional, isto é, dos processos constitucionalmente destinados ao controle de constitucionalidade dos atos estatais, à garantia da observância disposições constitucionais referentes ao pacto federativo, à solução de conflitos entre as funções do Estado (entre seus órgãos máximos) e à proteção dos direitos fundamentais.

Essa distinção, comum nos Estados em que o exercício da jurisdição constitucional é de competência restrita dos tribunais constitucionais, se mostra problemática e pouco ou nada útil concretamente no Brasil.

Isso porque, em primeiro plano, estabelecida a Constituição como base de validade de todo o ordenamento, inclusive o processual, não há, consequentemente, qualquer processo ou norma de direito processual que não deva guardar direta vinculação reflexiva do texto constitucional. Desta feita, "não há Direito Processual que não deva ser, nesse sentido, 'constitucional"'52.

E, em segundo plano, porque o controle de constitucionalidade é exercido não apenas de maneira concentrada - perante o Supremo Tribunal Federal, por meio as ações constitucionais próprias -, mas também difuso e incidental, permitindo a qualquer cidadão hipoteticamente atingido por ato estatal inconstitucional - qualquer ato estatal, e não apenas lei stricto sensu questionar sua validade perante qualquer órgão do judiciário - inclusive o juízo monocrático e não apenas os colegiados dos tribunais, desde que competente conforme as regras específicas dos ordenamentos dos processos civil, penal ou trabalhista, conforme o caso - como preliminar de mérito ${ }^{53}$.

52 CATtONI DE OLIVEIRA, Marcelo Andrade. Direito Constitucional Processual e Direito Processual Constitucional: limites da distinção em face do modelo constitucional brasileiro do controle jurisdicional de constitucionalidade. In: CATTONI DE OLIVEIRA, Marcelo (coord). Jurisdição e Hermenêutica Constitucional no Estado Democrático de Direito, p. 464.

${ }^{53}$ CATTONI DE OLIVEIRA, Marcelo Andrade. Direito Processual Constitucional, p. 212.

${ }^{54}$ No mesmo sentido, Lênio Luiz Streck ensina que "ao contrário do que ocorre na maioria dos países da Europa que a partir do segundo pós-guerra estabeleceram Tribunais Constitucionais com a tarefa de controlar a constitucionalidade, onde a questão da inconstitucionalidade é julgada per saltum (exceção feita a Portugal, que manteve, ao lado do controle concentrado preventivo e sucessivo, o controle difuso) -, no Brasil qualquer juiz de 
Revista Eletrônica de Direito Processual - REDP. Volume 16. Julho a dezembro de 2015

Periódico Semestral da Pós-Graduação Stricto Sensu em Direito Processual da UERJ

Patrono: José Carlos Barbosa Moreira. ISSN 1982-7636. pp. 157-188 http://www.e-publicacoes.uerj.br/index.php/redp/index

Aliás, na opinião de Álvaro Ricardo de Souza Cruz, é essa característica do modelo de controle de constitucionalidade adotado no Brasil (misto, ou seja, prevendo tanto o controle concentrado como o difuso de constitucionalidade) que garante a ampla participação dos cidadãos, de modo a tornar a sociedade co-intérprete da Constituição ${ }^{55}$.

Diante disso, caminhou-se no sentido de abandonar a distinção entre Direito Constitucional Processual e Direito Processual Constitucional, e a tratar ambos os temas sob a denominação de Direito Processual Constitucional. E é nesse contexto que, como já dito anteriormente, o processo - agora ressemantizado para processo constitucional - deve ser compreendido como uma metodologia de garantia de direitos fundamentais, consistente em uma "base principiológica uníssona aplicável a todo e qualquer processo" ${ }^{\circ 6}$. Essa metodologia essa se manifestará normativa e concretamente tanto por meio de procedimentos (processos) expressamente previstos no texto constitucional para instrumentalização do controle de constitucionalidade perante o Tribunal Constitucional (Supremo Tribunal Federal) como pela estruturação de um modelo constitucionalizado, a servir de forma para todo e qualquer processo, o chamado modelo constitucional de processo $^{57}$, para fazer uso da terminologia de Italo Andolina e Giuseppe Vignera ${ }^{58}$.

direito de primeira instância pode deixar de aplicar uma lei, se entendê-la inconstitucional" (Jurisdição Constitucional e Decisão Jurídica, p. 526).

${ }^{55}$ De fato, a defesa da tese é feita em diversas oportunidades por Álvaro Ricardo de Souza Cruz, trazendo-se aqui, a guisa de ilustração, duas delas, nas quais de maneira semelhante se manifesta o citado autor: "A participação ativa dos cidadãos torna toda a sociedade co-intérprete da Constituição. Mas isso somente se dará pela via difusa da jurisdição constitucional. Somente nessa seara a violação concreta aos direitos fundamentais encontra limites. Haja vista o histórico exemplo do confisco do governo Collor de Mello, pois ali, num primeiro momento, o Supremo Tribunal Federal permaneceu inerte, sendo que as primeiras instâncias do judiciário corajosamente fizeram frente àquela absurda arbitrariedade" (Hermenêutica Constitucional e Democracia. Revista da Faculdade Mineira de Direito, v. 3, n. 5 e 6, p. 36).

56 BARROS, Flaviane de Magalhães. (Re)Forma do Processo Penal: comentários críticos dos artigos modificados pelas Leis n. 11.690/08 e n. 11.719/08, p. 14.

${ }^{57}$ ANDOLINA, Italo. O papel do processo na atuação do ordenamento constitucional e transnacional. Revista de Processo. v. 87, p. 64. No mesmo sentido, ANDOLINA, Italo; VIGNERA, Giuseppe. I fondamenti constituzionali della giustuzia civile.

${ }^{58}$ Embora a terminologia processo constitucional já esteja consagrada - e, de fato, seja a mais adequada -, alguns autores brasileiros preferem valer-se da expressão processo justo, tradução literal de giusto processo, por vezes utilizadas em obras italianas, como é o caso de Leonardo Greco (Estudos de Direito Processual). Aliás, o próprio Italo Andolina, como já mencionado, um dos responsáveis pela evolução do processo constitucional, em determinada ocasião valeu-se da terminologia processo justo no sentido de processo constitucional ( $O$ papel do processo na atuação do ordenamento constitucional e transnacional. Revista de Processo. v. 87, p. 66). Esse esclarecimento se faz necessário para evitar que o leitor menos atento acabe se confundindo e compreendendo a expressão (processo justo) de acordo com a vertente instrumentalista e não com seu real e correto significado. 
Revista Eletrônica de Direito Processual - REDP. Volume 16. Julho a dezembro de 2015

Periódico Semestral da Pós-Graduação Stricto Sensu em Direito Processual da UERJ

Patrono: José Carlos Barbosa Moreira. ISSN 1982-7636. pp. 157-188 http://www.e-publicacoes.uerj.br/index.php/redp/index

3.2. Bases estruturantes do processo constitucional

Ao analisar a metodologia do processo constitucional, Ronaldo Brêtas defende que sua viga-mestra é o devido processo legal, concebendo-o tomando por base:

os pontos estruturais adiante enumerados, que formatam o devido processo constitucional, ou modelo constitucional de processo: a) o direito de ação (direito de postular a jurisdição); b) o direito de ampla defesa; c) o direito ao advogado e ao defensor público; d) o direito ao procedimento desenvolvido em contraditório; d) o direito à produção da prova; e) o direito ao processo sem dilações indevidas, de sorte a ser obtida uma decisão jurisdicional em prazo razoável; f) o direito a uma decisão proferida por órgão jurisdicional previamente definido no texto constitucional (juízo natural ou juízo constitucional) e fundamentada no ordenamento jurídico vigente (reserva legal); g) o direito ao recurso, na perspectiva de co-extensão do direito de ampla defesa. ${ }^{59}$

No mesmo sentido, Flaviane de Magalhães Barros ensina que a noção de modelo constitucional "abarca-se como pontos iniciais de referência para compreensão das garantias do processo o princípio do contraditório, o da ampla argumentação, o da fundamentação das decisões e o da participação de um terceiro imparcial" 60 . Note-se que ambos trabalham a partir da mesma base garantística como estruturante do modelo constitucional de processo, embora a segunda - por opção metodológica - resuma em quatro garantias ${ }^{61}$ o rol de direitos apresentados

\footnotetext{
${ }^{59}$ Processo Constitucional e Estado Democrático de Direito, p. 94.

60 Ao menos em duas ocasiões Flaviane de Magalhães Barros trabalha sob essa perspectiva: em $O$ modelo constitucional de processo e o processo penal: a necessidade de uma interpretação das reformas do processo penal a partir da Constituição. iMACHADO, Felipe Daniel Amorim; CATTONI DE OLIVEIRA, Marcelo Andrade (coords.). Constituição e Processo: a contribuição do processo ao constitucionalismo brasileiro, $p$. 334; e em (Re)Forma do Processo Penal: comentários críticos dos artigos modificados pelas Leis n. 11.690/08 e n. 11.719/08, p. 15 .

${ }^{61}$ Flaviane de Magalhães Barros utiliza a expressão princípios, a qual é compreendida aqui como garantia, terminologia mais adequada à natureza jurídica dos institutos ora trabalhados, na esteira do pensamento de Ronaldo Brêtas em obra inúmeras vezes referida neste trabalho.
} 
Revista Eletrônica de Direito Processual - REDP. Volume 16. Julho a dezembro de 2015

Periódico Semestral da Pós-Graduação Stricto Sensu em Direito Processual da UERJ

Patrono: José Carlos Barbosa Moreira. ISSN 1982-7636. pp. 157-188

http://www.e-publicacoes.uerj.br/index.php/redp/index

pelo primeiro $^{62}$, o que, perceba-se não prejudica em nada a análise, desdobrando-se tais garantias naquele rol de direitos.

\subsubsection{O contraditório}

O texto constitucional de 1988 , em seu art. $5^{\circ}, \mathrm{LV}$, fixa a garantia do contraditório aos litigantes em processo judicial ou administrativo, e aos acusados em geral ${ }^{63}$.

Esse princípio, essencial - para não dizer o mais importante no modelo constitucional de processo - por muito tempo foi enxergado de maneira míope e, consequentemente, atrofiado em sua aplicação concreta.

Isso porque, trabalhando-se o processo ainda sob a perspectiva da teoria da relação jurídica - por muito tempo não criticada - o contraditório era compreendido simplesmente como “constituído por dois elementos: a) a informação; b) a reação (esta, meramente possibilitada nos casos de direitos disponíveis)" ${ }^{\text {"64 }}$. Como consequência, limitava-se ao direito de manifestação das partes no processo, ou o direito de dizer (autor) e contradizer (réu), sem que isso necessariamente impactasse no ato decisório a ser praticado.

Na perspectiva do princípio do Estado Democrático de Direito, entretanto a garantia do contraditório deve ser relida, de modo a alcançar a plenitude de seu significado ou, como defende Rosemiro Pereira Leal "referente lógico-jurídico do processo constitucionalizado, traduzindo, em seus conteúdos, pela dialeticidade necessária entre interlocutores que se postam

\footnotetext{
${ }^{62}$ No mesmo sentido, Ulisses Moura Dalle sustenta que "o processo constitucional, entendido como garantia constitutiva de direitos fundamentais, apresenta-se sob a forma de verdadeiro modelo constitucional do processo, consubstanciado pelos princípios do contraditório, ampla argumentação terceiro imparcial e fundamentação das decisões, princípios que configuram uma base principiológica uníssona na qual o contraditório, em sua correlação com a fundamentação das decisões, constitui o centro em torno do qual gravitam os demais princípios" (Legalidade e arbitrio no processo jurisdicional democrático. Revista Eletrônica de Direito Processual. v. XIII, p. 848).

${ }^{63}$ Inquestionável é a lição de Ronaldo Brêtas quando esclarece que, já em 1865, Adolf Wach realçava a importância do contraditório para o processo, caminho também trilhado por outros juristas ao longo do Século XX, como Piero Calamandrei, na Itália, e José Frederico Marques, no Brasil, demonstrando que, a atual concepção de contraditório no texto constitucional brasileiro de 1988, teve sua gestação iniciada há cerca de um século e meio (Processo Constitucional e Estado Democrático de Direito, 96-97).

${ }^{64}$ CINTRA, Antônio Carlos de Araújo; GRINOVER, Ada Pellegrini; DINAMARCO, Cândido Rangel. Teoria Geral do Processo, p. 57.
} 
Revista Eletrônica de Direito Processual - REDP. Volume 16. Julho a dezembro de 2015

Periódico Semestral da Pós-Graduação Stricto Sensu em Direito Processual da UERJ

Patrono: José Carlos Barbosa Moreira. ISSN 1982-7636. pp. 157-188 http://www.e-publicacoes.uerj.br/index.php/redp/index

em defesa ou disputa de direitos alegados, podendo até mesmo exercer a liberdade de nada dizer" ${ }^{65}$. E, em semelhante sentido, sustenta Leonardo Greco que:

O princípio do contraditório pode ser definido como aquele segundo o qual ninguém pode ser atingido por uma decisão judicial na sua esfera de interesses, sem ter tido a ampla possibilidade de influir eficazmente na sua formação em igualdade de condições com a parte contrária. O contraditório é a expressão processual do princípio político da participação democrática, que hoje rege as relações entre o Estado e os cidadãos na Democracia contemporânea. ${ }^{66}$

Além disso, o contraditório fixa, para o decisor, um dever de consulta, "impondo o fomento do debate preventivo e a submissão de todos os fundamentos da futura decisão ao contraditório"67 68. Trata-se, então, da garantia de participação dos interessados, não como coadjuvantes, mas como atores principais, nos atos processuais destinados à preparação do provimento estatal cujos efeitos possam atingi-los.

Isso significa que o contraditório: a) é garantido a ambas as partes do processo (autor e réu, demandante e demandado, reclamante e reclamado, querelante e querelado, acusador e acusado, exequente e executado); b) requer que as partes estejam em simétrica paridade, o que também pode ser traduzido por garantia de paridade de armas, vedando-se o estabelecimento diferenciado dos instrumentos de defesa entre elas ${ }^{69}$; c) "deve garantir às partes o direito de

${ }^{65}$ LEAL, Rosemiro Pereira. Processo e hermenêutica constitucional a partir do Estado Democrático de Direito. In: LEAL, Rosemiro Pereira (coord.). Estudos Continuados de teoria do processo, v. 2, p. 88.

${ }^{66}$ GRECO, Leonardo. Instituições de Processo Civil, v I, p. 451.

${ }^{67}$ NUNES, Dierle José Coelho. Direito Jurisdicional Democrático, p. 226.

${ }^{68}$ Exemplo da materialidade dessa exigência se verifica na nova redação do art. 384 do Código de Processo Penal, que trata do instituto da mutatio libeli. Alterado pela Lei n. 11.719/2008, referido dispositivo, desde então, veda ao juiz unilateralmente alterar a capitulação da acusação ao final da instrução caso, ao longo de seu trâmite, suspeite a capitulação original estava incorreta. Longe disso, sua atribuição, nesse ponto, se limita ao envio dos autos ao acusador para que este, entendendo ser o caso, solicite a referida alteração (SILVA, Fernando Laércio Alves da. A Mutatio Libeli na reforma processual penal brasileira: uma releitura do instituto à luz do Modelo Constitucional de Processo Penal. Revista Eletrônica de Direito Processual. v. XIII, p. 190).

${ }^{69}$ Giuseppe Tarzia ensina que a preocupação com a correta configuração do contraditório, em especial no que tange à exigência da paridade de armas, não é exclusiva do Direito interno dos Estados, sendo tema frequente na Corte Européia. Nas palavras do autor: "La Corte europea ha ripetutamente ricordato que 'le principe de l'elalité des armes - l'un des élements de la notion plus large de procès équitable - requiert que chaque partie se voie offrir une possibilite raisonnable de présenter as cause dans des conditions qui ne la placent pas dans une situation de net désavantage par rapport à son adversaire" (L'Art. 111 Cost. e le Garanzie Europee del Processo Civile. Revista de Processo, n. 103, p. 164). 
Revista Eletrônica de Direito Processual - REDP. Volume 16. Julho a dezembro de 2015

Periódico Semestral da Pós-Graduação Stricto Sensu em Direito Processual da UERJ

Patrono: José Carlos Barbosa Moreira. ISSN 1982-7636. pp. 157-188 http://www.e-publicacoes.uerj.br/index.php/redp/index

influenciar no resultado da decisão por meio de suas argumentações, fatos e provas"70, configurando, portanto, garantia de não surpresa quanto.

Essa nova concepção de contraditório, de um lado, somente se complementa pela garantia da ampla defesa (ou ampla argumentação), igualmente prevista no art. $5^{\circ}, \mathrm{LV}$ da Constituição Federal de 1988, e, de outro, implica na exigência da fundamentação das decisões a serem proferidas pelo órgão estatal decisor imparcial.

\subsubsection{A ampla defesa}

Prevista, no texto constitucional brasileiro, no mesmo dispositivo do contraditório, também a ampla defesa é exigência do modelo constitucional do processo, o que, aliás, ressalta sua característica de coextensão da concepção de contraditório.

Tal como o contraditório, a ampla defesa tem sido analisada, desde longa data, a partir de uma perspectiva míope, limitada ao status de garantia do acusado (no processo penal) e da parte ré, demandado ou reclamado (nos processos civil e trabalhista), e se manifestando no direito à defesa por advogado e, especificamente no processo penal, da autodefesa no momento do interrogatório do acusado $^{71}$.

Essa visão, contudo, não encontra espaço em um processo estruturado à luz do princípio do Estado Democrático de Direito e que, ao mesmo tempo, objetiva concretização desse princípio. Longe disso, também a concepção de ampla defesa, no modelo constitucional de processo, é ressemantizada, fato que não escapou ao olhar de Rosemiro Pereira Leal que, sobre o instituto, dissertou:

A amplitude de defesa não supõe infinitude de produção da defesa a qualquer tempo, porém, que esta se produza pelos meios e elementos totais de alegações e provas no tempo processual oportunizado na lei. Há de ser ampla, porque não pode ser estreitada (comprimida) pela sumarização do tempo a tal ponto de excluir a

\footnotetext{
${ }^{70}$ SOARES, Carlos Henrique. Estatuto da Advocacia e Processo Constitucional: com questões de múltipla escolha sobre o Estatuto da Advocacia e Ética aplicadas nos últimos exames da OAB, p. 296.

${ }^{71}$ Essa é a perspectiva apresentada por Antônio Carlos de Araújo Cintra, Ada Pellegrini Grinover e Cândido Rangel Dinamarco (Teoria Geral do Processo, p. 56).
} 
Revista Eletrônica de Direito Processual - REDP. Volume 16. Julho a dezembro de 2015

Periódico Semestral da Pós-Graduação Stricto Sensu em Direito Processual da UERJ

Patrono: José Carlos Barbosa Moreira. ISSN 1982-7636. pp. 157-188 http://www.e-publicacoes.uerj.br/index.php/redp/index

liberdade de reflexão cômoda dos aspectos fundamentais de sua produção eficiente. $^{72}$

Perceba-se: a ampla defesa ainda contempla o direito à defesa técnica por advogado previsto, inclusive, como "indispensável à administração da justiça” no art. 133, da Constituição Federal de $1988^{73}$ - e, no processo penal, igualmente o interrogatório como meio de defesa, mas não se limita a isso. No modelo constitucional de processo, a ampla defesa requer, além dos elementos acima, que se garanta às partes amplitude argumentativa, ou seja, a possibilidade de aduzir suas teses e argumentos em tempo e modo hábil, bem como de produzir os meios de prova - desde que lícitos - necessários à comprovação dos mesmos ${ }^{74}$.

\subsubsection{A necessidade de fundamentação das decisões}

No modelo constitucional de processo, a necessidade ou exigência de fundamentação das decisões decorre logicamente do contraditório, configurando, em essência, o modo pelo qual se resguarda, no caso concreto, que o julgador, no momento de proferir sua decisão, pautou-se exclusivamente pelos argumentos e provas produzidos pelas partes em contraditório. Nas palavras de André Cordeiro Leal, "não basta, pois, que às partes sejam dadas iguais oportunidades de pronunciamento, mas que esse pronunciamento seja efetivamente considerado quando da prolatação das decisões, porque, se assim não ocorrer, haverá negativa de vigência aos princípios do processo (...)". ${ }^{75}$

\footnotetext{
${ }^{72}$ Teoria Geral do Processo: primeiros estudos, p. 100.

${ }^{73}$ Carlos Henrique Soares, nesse sentido, sustenta que o advogado é "garantidor da legitimidade da decisão judicial, uma vez que é o mesmo o juridicamente capaz de estabelecer um diálogo técnico-jurídico que permite a construção do provimento em simétrica paridade, garantindo o contraditório e a ampla defesa, bem como um controle da jurisdição, nos procedimentos litigiosos ou não, pouco importando o valor atribuído à causa" (Estatuto da Advocacia e Processo Constitucional: com questões de múltipla escolha sobre o Estatuto da Advocacia e Ética aplicadas nos últimos exames da OAB, p. 329).

${ }^{74}$ No mesmo sentido, Flaviane de Magalhães Barros ensina que "a ampla argumentação como garantia das partes, e não como um direito subjetivo de 'uma' parte, compreende a necessidade de se garantir o tempo do processo para que o esforço reconstrutivo dos argumentos do discurso dialético das partes possa ser apropriado, de modo a que todas as possibilidades de argumentação sejam perquiridas.(...) $\mathrm{Na}$ perspectiva do processo jurisdicional, da ampla argumentação decorre o direito à prova, à assistência de um advogado, à necessidade de se garantir que as partes possam ter o tempo processual para reconstruir o caso concreto e discutir quais normas jurídicas prima facie aplicáveis são mais adequadas ao caso concreto" [(Re)Forma do Processo Penal: comentários críticos dos artigos modificados pelas Leis n. 11.690/08 e n. 11.719/08, p. 20].

${ }^{75} \mathrm{O}$ contraditório e a fundamentação das decisões do direito processual democrático, p. 104.
} 
Revista Eletrônica de Direito Processual - REDP. Volume 16. Julho a dezembro de 2015

Periódico Semestral da Pós-Graduação Stricto Sensu em Direito Processual da UERJ

Patrono: José Carlos Barbosa Moreira. ISSN 1982-7636. pp. 157-188 http://www.e-publicacoes.uerj.br/index.php/redp/index

Em outras palavras, mais do que apresentar às partes - e à sociedade - os motivos nos quais se baseia para alcançar tal o qual decisão, exige-se que a atividade decisória esteja efetivamente vinculada a toda a atividade preparatória realizada pelas partes ao longo do procedimento.

Não significa isso dizer que o decisor deve ser absolutamente objetivo, mesmo porque, tratando-se de um ser humano, o subjetivismo está em sua essência. Implica, isso sim, estabelecer-se a racionalidade das decisões - e diga-se de passagem todas as decisões a serem tomadas ao ,longo do processo, e não apenas o provimento final - de maneira vinculada ao que fora objeto do contraditório, vedada a justificação “abstrata, desordenada, desvairada, ilógica, irracional, discricionária ou arbitrária, formulada ao influxo das ideologias, do particular sentimento de justiça, do livre espírito de equidade, do prudente arbítrio ou das convicções pessoais do agente público julgador" 76 .

Somente assim, se impede a ocorrência de decisões-surpresa e, ainda que venham a ocorrer, podem ser combatidas pelas partes por meio dos instrumentos recursais pertinentes.

\subsubsection{A imparcialidade do decisor}

A quarta garantia elencada como estrutural do processo constitucional por Flaviane de Magalhães Barros é a da imparcialidade do decisor ou julgador. Novamente se verifica a presença de um instituto que se liga umbilicalmente ao contraditório.

Necessário, inclusive, se faz esclarecer que, no modelo constitucional de processo, a imparcialidade do julgador não pode ser confundida com passividade ou absoluta paralisia do julgador.

Deve restar esclarecido - e essa observação se mostra primordial ao objetivo do presente estudo - que o juiz deve participar atentamente ${ }^{77}$, interagindo e dialogando, inclusive, com as partes e suas argumentações, sob pena dessas manifestações não surtirem eficácia na construção da decisão a ser tomada por aquele. Não obstante isso, ele, o juiz, não participa do contraditório. Isso significa dizer que ele, o juiz, não pode assumir funções típicas de parte, praticar atos,

\footnotetext{
${ }^{76}$ BRÊTAS, Ronaldo de Carvalho Dias. Processo Constitucional e Estado Democrático de Direito, p. 132.

${ }^{77}$ GONÇALVES, Aroldo Plínio. Técnica Processual e Teoria do Processo, p. 105.
} 
Revista Eletrônica de Direito Processual - REDP. Volume 16. Julho a dezembro de 2015

Periódico Semestral da Pós-Graduação Stricto Sensu em Direito Processual da UERJ

Patrono: José Carlos Barbosa Moreira. ISSN 1982-7636. pp. 157-188 http://www.e-publicacoes.uerj.br/index.php/redp/index

manter relações ou mesmo conexões de fato que possam expressar posições psíquicas a favor ou contra uma das partes ${ }^{78}$.

Deve o leitor atentar-se, entretanto, que a garantia da imparcialidade do juiz não se confunde com o princípio do juízo natural ou juízo constitucional, previsto, no Brasil, no art. $5^{\circ}$, XXXVII da Constituição Federal de 1988 e que compreende "a coexistência do Estado Democrático de Direito e de seus órgãos jurisdicionais, com competências predefinidas, ante os atos ou fatos a serem julgados"79. Aliás, por si só, o princípio do juízo natural sequer garante a imparcialidade do juiz.

3.3. O processo constitucional e sua aplicação para além do processo judicial

Pode-se dizer, na esteira do ensinamento de Flaviane de Magalhães Barros, que modelo constitucional de processo - ou processo constitucional - possui três importantes características: expansividade, variabilidade e perfectibilidade ${ }^{80}$.

E é exatamente a partir dessas características do processo constitucional que a sua aplicabilidade enquanto metodologia de garantia de direitos fundamentais não se restrinja à função estatal judiciária, mas também alcance as funções legislativa e executiva.

De fato, como bem apresenta André Del Negri, "na Teoria Democrática, o Processo é uma instituição regente e legitimadora dos atos decisionais das funções público-estatais"81. Isso porque, tomando-se por premissas, de um lado, a necessidade da discursividade para a legitimação dos atos estatais aptos a impactar na vida dos cidadãos e, de outro, o reconhecimento do processo como locus mais apropriado para o exercício democrático, o modelo constitucional

\footnotetext{
${ }^{78}$ VADELL, Lorenzo M. Bujoso. Direito Processual Penal: novas orientações. In: DIDIER Jr., Fredie (coord.). Teoria Geral do Processo: panorama mundial. v. 02, p. 506.

${ }^{79}$ LEAL, Rosemiro Pereira. Teoria Geral do Processo: primeiros estudos, p. 119.

${ }^{80}$ Sobre tais características, ensina Flaviane de Magalhães Barros que "a expansividade, que garante a idoneidade para que a norma processual possa ser expandida para microssistemas, desde que mantenha sua conformidade com o esquema geral de processo; a variabilidade, como a possibilidade de a norma processual especializar-se e assumir forma diversa em função de característica específica de um determinado microssistema, desde que em conformidade com a base constitucional; e, por fim, a perfectibilidade, como a capacidade de o modelo constitucional aperfeiçoar-se e definir novos institutos por meio do processo legislativo, mas sempre de acordo com o esquema geral. [Nulidades e Modelo Constitucional de processo. In: DIDIER Jr., Fredie (coord.). Teoria Geral do Processo: panorama mundial. v. 02, p. 245-246].

${ }^{81}$ DEL NEGRI, André Luis. Teoria da Constituição e do Direito Constitucional, p. 345.
} 
Revista Eletrônica de Direito Processual - REDP. Volume 16. Julho a dezembro de 2015

Periódico Semestral da Pós-Graduação Stricto Sensu em Direito Processual da UERJ

Patrono: José Carlos Barbosa Moreira. ISSN 1982-7636. pp. 157-188 http://www.e-publicacoes.uerj.br/index.php/redp/index

de processo se estende - e, de fato, deve se estender - para além da função judiciária, passando a balizar as demais atividades estatais.

Não se trata, que isso reste esclarecido, de uma burocratização das atividades estatais, mas sim, do reconhecimento da metodologia do processo constitucional, por todas as garantias que lhe são inerentes, como a mais adequada e propícia ao exercício da fiscalidade democrática e, consequentemente, da legitimação dos atos decisórios estatais.

\section{Considerações finais}

Partindo da proposta inicial de discutir a correta relação que se estabelece entre Constituição e Processo no Brasil, tendo em vista o advento da Constituição Federal de 1988 e, a partir de então, demonstrar o que, realmente, se deve compreender por processo constitucional no Estado Democrático de Direito e o contributo que ele tem a oferecer para a conformação do Brasil como um efetivo Estado Democrático de Direito, este breve trabalho buscou lançar ainda que perfunctoriamente - algumas reflexões em torno da xifópaga relação estabelecida entre Estado Democrático de Direito e Processo Constitucional ou Modelo Constitucional de Processo.

Essas reflexões, embora não inovadoras - eis que já apresentadas por diversos autores , ainda hoje se mostram necessárias, seja porque muitos desses autores, como demonstrado no estudo, partem de premissas equivocadas, ora confundindo-se sobre a natureza e a concepção de Estado Democrático de Direito, ora confundindo-se em relação à natureza, a concepção e os elementos do processo, ora, ainda, confundindo-se quanto a ambos.

Nesse sentido, a fim de superar tantos equívocos, buscou-se, no presente texto, apresentar os esclarecimentos necessários a partir das linhas de pensamento com base nas quais a teoria do processo constitucional como metodologia de garantia de direitos fundamentais no Estado Democrático de Direito foi, ao longo do tempo, estruturada, desde a proposta original de Kelsen para um Tribunal Constitucional, passando por Elio Fazzalari, José Alfredo de Oliveira Baracho, Ítalo Andolina e Giuseppe Vignera, seus interlocutores e discípulos mais atuais, a exemplo de Rosemiro Pereira Leal, Ronaldo Brêtas de Carvalho Dias, Flaviane de Magalhães Barros, André Cordeiro Leal, Dierle José Coelho Nunes e André Luís Del Negri. 
Revista Eletrônica de Direito Processual - REDP. Volume 16. Julho a dezembro de 2015

Periódico Semestral da Pós-Graduação Stricto Sensu em Direito Processual da UERJ

Patrono: José Carlos Barbosa Moreira. ISSN 1982-7636. pp. 157-188 http://www.e-publicacoes.uerj.br/index.php/redp/index

Ao final dessa empreitada, algumas conclusões foram alcançadas, as quais passa-se a expor agora.

Em primeiro plano, e talvez a mais óbvia, conclui-se que a história político-jurídica brasileira, ao contrário do que a leitura superficial de pequenos trechos de muitas das Constituições vigentes desde 1824, é marcada pelo autoritarismo e a completa ausência de identificação com o princípio do Estado Democrático de Direito, identidade essa que somente se passa a buscar com mais vigor a partir da Constituição Federal de 1988.

Nesse contexto, em segundo plano, se conclui que, embora José Alfredo de Oliveira Baracho tenha introduzido a teoria do processo constitucional no Brasil em 1984, e que alguns de seus elementos desde longa data já fossem defendidos por outros autores no nível internacional, como Hector Fix-Zamudio, no México, Piero Calamandrei, Ítalo Andolina e Giuseppe Vignera, na Itália, e outros tantos, no Brasil, referida teoria encontra campo fértil para desenvolver-se somente a partir da já citada Constituição de 1988. Não que o ordenamento brasileiro fosse alheio às garantias que compõem a base estruturante do processo constitucional, mesmo porque, a leitura, ainda que superficial, de textos legais e doutrinários anteriores a 1988 demonstram o contrário. O que ocorria - e grandes resquícios disso ainda se verificam - era a leitura equivocada desses institutos, a partir de premissas não condizentes com o modelo constitucional de processo, a dizer, a concepção do Brasil como um Estado Social e do processo como relação jurídica, base da escola instrumentalista, até hoje dominante.

Em terceiro plano, conclui-se que o processo constitucional, ou modelo constitucional de processo, atualmente, não se limite à atividade de promoção do controle de constitucionalidade das normas, consistindo, isto sim, em uma metodologia de concepção do processo voltado à realização da discursividade democrática e, consequentemente, imprimindo a necessidade da ressemantização de diversos institutos processuais, em especial o contraditório, a ampla defesa ou ampla argumentação, a exigência de fundamentação das decisões e a imparcialidade do juiz, imprescindíveis à configuração do devido processo legal - ou devido processo constitucional. Somente a partir dessa ressemantização e da obediência plena aos elementos do processo constitucional, se alcançará a legitimidade nos atos decisórios estatais.

E, em quarto e último plano, conclui-se que a metodologia instituída pelo processo constitucional não se restringe - e nem pode restar restringida - ao processo judicial, tratando- 
Revista Eletrônica de Direito Processual - REDP. Volume 16. Julho a dezembro de 2015

Periódico Semestral da Pós-Graduação Stricto Sensu em Direito Processual da UERJ

Patrono: José Carlos Barbosa Moreira. ISSN 1982-7636. pp. 157-188 http://www.e-publicacoes.uerj.br/index.php/redp/index

se, por suas características de expansividade, variabilidade e perfectibilidade, da base sobre a qual toda a atividade decisória estatal - legislativa, executiva e judiciária - deve se desenvolver, sob pena de não atendimento à democraticidade exigida pelo texto constitucional de 1988 .

Desta feita, derradeiramente pode-se afirmar seguramente que o processo constitucional é, na atual quadra histórico-político-normativa brasileira, o instrumento devido e necessário à concretização do Estado Democrático de Direito no Brasil.

\section{REFERÊNCIAS BIBLIOGRÁFICAS}

ANDOLINA, Italo. O papel do processo na atuação do ordenamento constitucional $e$ transnacional. Revista de Processo. Trad. Orestes Nestor de Souza Laspro. São Paulo: RT, v. 87, p. 63-69, jul/set. 1997.

ANDOLINA, Italo; VIGNERA, Giuseppe. I fondamenti constituzionali della giustuzia civile. Torino: G. Giappichelli, 1997.

ARAÚJO, Marcelo Cunha de. O Novo Processo Constitucional. Belo Horizonte: Mandamentos, 2003.

BARACHO, José Alfredo de Oliveira. Processo Constitucional. Rio de Janeiro: Forense, 1984. BARACHO, José Alfredo de Oliveira. Processo Constitucional. Revista Forense. Rio de Janeiro: Forense, v. 337, p. 105-123, jan/mar. 1997.

BARACHO, José Alfredo de Oliveira. Teoria Geral do Processo Constitucional. Revista da Faculdade Mineira de Direito. Belo Horizonte: PUCMINAS, v. 2, n. 3 e 4, p. 89-154, $1^{\circ}$ e $2^{\circ}$ sem. 1999.

BARROS, Flaviane de Magalhães. (Re)Forma do Processo Penal: comentários críticos dos artigos modificados pelas Leis n. 11.690/08 e n. 11.719/08. Belo Horizonte: Del Rey, 2008. BARROS Flaviane de Magalhães. O modelo constitucional de processo e o processo penal: a necessidade de uma interpretação das reformas do processo penal a partir da Constituição. In: MACHADO, Felipe Daniel Amorim; CATTONI DE OLIVEIRA, Marcelo Andrade (coords.). Constituição e Processo: a contribuição do processo ao constitucionalismo brasileiro. Belo Horizonte: Del Rey, 2009. 
Revista Eletrônica de Direito Processual - REDP. Volume 16. Julho a dezembro de 2015

Periódico Semestral da Pós-Graduação Stricto Sensu em Direito Processual da UERJ

Patrono: José Carlos Barbosa Moreira. ISSN 1982-7636. pp. 157-188 http://www.e-publicacoes.uerj.br/index.php/redp/index

BARROS, Flaviane de Magalhães. Nulidades e Modelo Constitucional de processo. In: DIDIER

Jr., Fredie (coord.). Teoria Geral do Processo: panorama mundial. v. 02. Salvador: Juspodivum, 2010.

BARROSO, Luis Roberto; BARCELlOS, Ana Paula de. O começo da história: a nova interpretação constitucional e o papel dos princípios no Direito Brasileiro. In: SILVA, Virgílio Afonso da (org.). Interpretação Constitucional. 1.ed. $2^{\mathrm{a}}$ tiragem. São Paulo: Malheiros, 2010. BARROSO, Luis Roberto. O Constitucionalismo Democrático no Brasil: crônica de um sucesso imprevisto. In: GUERRA, Roberta Freitas; SILVA, Fernando Laércio Alves da;DEL NERO, Patrícia Aurélia (org). Neoconstitucionalismo em perspectiva. Viçosa: UFV, 2014. BONAVIDES, Paulo. Curso de Direito Constitucional. 22.ed. São Paulo: Malheiros, 2008. BRÊTAS, Ronaldo de Carvalho Dias. Processo Constitucional e Estado Democrático de Direito. 2.ed. Belo Horizonte: Del Rey, 2012.

BÜLOW, Oskar Von. La Teoria de las Excepciones Procesales y los Presupuestos Procesales. Trad. Miguel Angel Rosas Lichtschein. Rodamillans: El Foro, 1964.

CALMON DE PASSOS, Joaquim José. Processo e Democracia. In: GRINOVER, Ada Pellegrini; DINAMARCO, Cândido Rangel; WATANABE, Kazuo (coord.). Participação e processo. São Paulo: RT, 1988.

CARVAlHO NETTO, Menelick de. A Hermenêutica Constitucional sob o paradigma do Estado Democrático de Direito. In: CATTONI DE OLIVEIRA, Marcelo Andrade (coord.). Jurisdição e Hermenêutica Constitucional no Estado Democrático de Direito. Belo Horizonte: Mandamentos, 2004.

CATTONI DE OLIVEIRA, Marcelo Andrade. O processo constitucional como instrumento da jurisdição constitucional. Revista da Faculdade Mineira de Direito. Belo Horizonte: PUCMINAS, v. 3, n. 5 e 6, p. 161-170, $1^{\circ}$ e $2^{\circ}$ sem. 2000.

CATtONi DE OLIVEIRA, Marcelo Andrade. Direito Processual Constitucional. Belo Horizonte: Mandamentos, 2001.

CATTONI DE OLIVEIRA, Marcelo Andrade. Direito Constitucional. Belo Horizonte: Mandamentos, 2002.

CATTONI DE OLIVEIRA, Marcelo Andrade. Direito Constitucional Processual e Direito Processual Constitucional: limites da distinção em face do modelo constitucional brasileiro do 
Revista Eletrônica de Direito Processual - REDP. Volume 16. Julho a dezembro de 2015

Periódico Semestral da Pós-Graduação Stricto Sensu em Direito Processual da UERJ

Patrono: José Carlos Barbosa Moreira. ISSN 1982-7636. pp. 157-188 http://www.e-publicacoes.uerj.br/index.php/redp/index

controle jurisdicional de constitucionalidade. In: CATTONI DE OLIVEIRA, Marcelo (coord).

Jurisdição e Hermenêutica Constitucional no Estado Democrático de Direito. Belo Horizonte: Mandamentos, 2004.

CINTRA, Antônio Carlos de Araújo; GRINOVER, Ada Pellegrini; DINAMARCO, Cândido Rangel. Teoria Geral do Processo. 14.ed. São Paulo: Malheiros, 1998.

CITTADINO, Gisele. Pluralismo, Direito e Justiça Distributiva: Elementos da Filosofia Constitucional Contemporânea. 3a . ed. Rio de Janeiro: Lumen Juris, 2004.

CRUZ, Álvaro Ricardo de Souza. Hermenêutica Constitucional e Democracia. Revista da Faculdade Mineira de Direito. Belo Horizonte: PUCMINAS, v. 3, n.5 e 6, p. 17-39, $1^{\circ}$ e $2^{\circ}$ sem. 2000 .

DALLE, Ulisses Moura. Legalidade e arbitrio no processo jurisdicional democrático. Revista Eletrônica de Direito Processual. Rio de Janeiro: UERJ, ano 8, v. XIII, p. 835-857, jan/jun. 2014.

DEL NEGRI, André Luis. Controle de Constitucionalidade no Processo Legislativo: teoria da legitimidade democrática. 2. ed. Belo Horizonte: Fórum, 2008.

DEL NEGRI, André Luis. Teoria da Constituição e do Direito Constitucional. Belo Horizonte: Fórum, 2009.

DEL NEGRI, André Luis. Processo Constitucional e Decisão Interna Corporis. Belo Horizonte: Fórum, 2011.

DINAMARCO, Cândido Rangel. A Instrumentalidade do Processo. 14.ed. São Paulo: Malheiros, 2009.

FAZZALARI, Elio. Instituições de Direito Processual. Traduzido por Eliane Nassif. Campinas: Bookseller, 2006.

GONÇAlVES, Aroldo Plínio. Técnica Processual e Teoria do Processo. 2.ed. Belo Horizonte: Del Rey, 2012.

GRECO, Leonardo. Estudos de Direito Processual. Campos dos Goytacazes: FDC, 2005.

GRECO, Leonardo. Instituições de Processo Civil, v. I. 4.ed. Rio de Janeiro: Forense, 2013.

HABERMAS, Jürgen. Direito e Democracia: entre a faticidade e a validade. v. II. 2.ed. Trad. Flávio Beno Siebeneicher. Rio de Janeiro: Tempo Brasileiro, 2011. 
Revista Eletrônica de Direito Processual - REDP. Volume 16. Julho a dezembro de 2015

Periódico Semestral da Pós-Graduação Stricto Sensu em Direito Processual da UERJ

Patrono: José Carlos Barbosa Moreira. ISSN 1982-7636. pp. 157-188 http://www.e-publicacoes.uerj.br/index.php/redp/index

LEAL, André Cordeiro. O Contraditório e a Fundamentação das Decisões no Direito

Processual Democrático. Belo Horizonte: Mandamentos, 2002.

LEAL, Rosemiro Pereira. Processo e hermenêutica constitucional a partir do Estado Democrático de Direito. In: LEAL, Rosemiro Pereira (coord.). Estudos Continuados de teoria do processo. v. 2. Porto Alegre: Síntese, 2001.

LEAL, Rosemiro Pereira. Teoria Geral do Processo: primeiros estudos. 11.ed. Rio de Janeiro: Forense, 2012.

MAC-GREGOR, Eduardo Ferrer. Forjadores del Derecho Procesual Constitucional. Buenos Aires: Ad-hoc, 2009.

MENDES, Gilmar Ferreira; MÁRTIRES COELHO, Inocêncio; GONET BRANCO, Paulo Gustavo. Curso de Direito Constitucional. 2.ed. São Paulo: Saraiva, 2008.

NUNES, Dierle José Coelho. Processo Jurisdicional Democrático. 1.ed. $4^{\text {a }}$ reimp. Curitiba: Juruá, 2012.

PORTANOVA, Rui. Princípios do Processo Civil. 3.ed. Porto Alegre: Livraria do Advogado, 1999.

SILVA, Fernando Laércio Alves da. Cidadania Participativa: o caso do orçamento municipal de Ipatinga-MG. Interesse Público. Porto Alegre: Notadez, ano 7, n. 33, p. 305-326, set./out. 2005.

SILVA, Fernando Laércio Alves da. A Mutatio Libeli na reforma processual penal brasileira: uma releitura do instituto à luz do Modelo Constitucional de Processo Penal. Revista Eletrônica de Direito Processual. Rio de Janeiro: UERJ, ano 8, v. XIII, p. 175-199, jan/jun. 2014.

SILVA, José Afonso da. Curso de Direito Constitucional Positivo. 30.ed. São Paulo: Malheiros, 2007.

SILVA, Virgílio Afonso. A Constitucionalização do Direito: Os direitos fundamentais nas

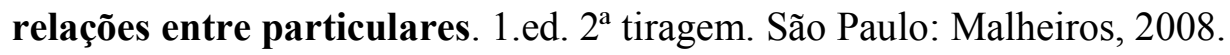

SOARES, Carlos Henrique. Estatuto da Advocacia e Processo Constitucional: com questões de múltipla escolha sobre o Estatuto da Advocacia e Ética aplicadas nos últimos exames da OAB. Belo Horizonte: Del Rey, 2014.

STRECK, Lênio Luiz. Jurisdição Constitucional e Decisão Jurídica. 4.ed. São Paulo: RT, 
Revista Eletrônica de Direito Processual - REDP. Volume 16. Julho a dezembro de 2015

Periódico Semestral da Pós-Graduação Stricto Sensu em Direito Processual da UERJ

Patrono: José Carlos Barbosa Moreira. ISSN 1982-7636. pp. 157-188 http://www.e-publicacoes.uerj.br/index.php/redp/index

2014.

TARZIA, Giuseppe. L'Art. 111 Cost. e le Garanzie Europee del Processo Civile. Revista de Processo. São Paulo: RT, v. 103, p. 156-174, jul/set. 2001.

TAVARES, Fernando Horta (coord.). Constituição e Processo: Princípios Constitucionais do Processo. Curitiba: Juruá, 2007.

TEODORO, Maria Cecília Máximo. O Juiz Ativo e os Direitos Trabalhistas. São Paulo: Ltr, 2011.

THIBAU, Vinicius Lott. O Direito à prova no paradigma jurídico-constitucional do Estado Democrático de Direito - considerações sobre a procedimentalidade brasileira. In: Fernando Horta Tavares (org.). Constituição, Direito e Processo: princípios constitucionais do processo. Curitiba: Juruá, 2007.

THIBAU, Vinícius Lott. Presunção e Prova no Direito Processual Democrático. Belo Horizonte: Arraes, 2011.

TOURINHO FILHO, Fernando da Costa Tourinho Filho. Processo Penal. v. 01. 33.ed. São Paulo: Saraiva, 2011.

VADELL, Lorenzo M. Bujoso. Direito Processual Penal: novas orientações. In: DIDIER Jr., Fredie (coord.). Teoria Geral do Processo: panorama mundial. v. 02. Salvador: Juspodivum, 2010.

VARGAS, José Cirilo. Processo Penal e Direitos Fundamentais. Belo Horizonte: Del Rey, 1992. 